\title{
The Minimum House Designs of Pioneer Modernists Eileen Gray and Charlotte Perriand
}

\author{
By Starlight Vattano* \\ Giorgia Gaeta ${ }^{\dagger}$
}

The article deals with the study of two projects of Eileen Gray, an architect who had turned her perception of reality into formal delicacy and Charlotte Perriand, who was able to promote the emphasis of collective and rational living. The article proposes the analysis of some unbuilt Eileen Gray and Charlotte Perriand's projects designed in response to the social problems arising in 1936. Their projects of minimum temporary houses are a manifesto through which they investigates other principles of the Modern Movement with the variety of composition of small spaces in relation to the inside well-being at the human scale. The redrawing practice, shown in this article as methodological training to enrich knowledge about the historiography of these two pioneers of Modern Movement allows improving existing data of modern architecture and especially about unbuilt projects here deepened and explicated through new and unpublished drawings.

\section{Introduction}

The period here analysed is characterized by the important innovative laws of the 1920's and 1930's. Indeed the French government had given more rights to the work-class and, for the first time, also paid holidays. Several architectural competitions were organized for the realization of leisure projects or, at a building scale, of minimum weekend houses through which, the last innovative technologies were experimented.

Among the most important figures who worked through rigorous and sophisticated survey methodologies, were Eileen Gray and Charlotte Perriand, two of the women pioneers of the Modern Movement, who presented their vision of minimum architecture for leisure and holidays. With this contribution we identify a part of their architectural philosophy of the economic and functional composition of volumes through a redrawing methodology that provides further reading keys represented by unpublished graphic representations.

${ }^{*}$ Architect, University of Palermo, Italy.

${ }^{\dagger}$ Architect, University of Palermo, Italy. 


\section{Eileen Gray. "Cabines Démontables pour Centre de Vacances"}

You can identify the enigmatic figure of Eileen Gray in a mixture of terms related on one hand to the symbolism of Wagner's Parsifal and on the other hand to the scientific rationalism of the Modern Movement. As reported by Caroline Constant, quoting the words of Jean Badovici on L'Architecture Vivante: «[...] She has interpreted this universal logic of forms and transmitted things, demonstrated with scientific thought, that our feelings do not yet know how to perceive the creation of an atmosphere of plastic infinity where planes are lost in each other, where each object is no longer limited by its particular form, but it transcends the external form taken as an element of mysterious unity lived beyond the materials» ${ }^{1}$.

A few built houses and all the unbuilt projects, sublimated on small paper sheets, describe the heterogeneous training and attitude of Eileen Gray to material manipulation. The literature about this eccentric and subversive woman reveals, within a personal drawing's code, the ability to reflect her emotions in architecture through an empathic practice of doing.

And this is known through the study of her archive drawings ranging from the scale of the minimum week-end house to the two large-scale unbuilt projects, the Centre de Vacances et de Loisirs (1936-37) and the Centre Culturel et Social (1946-47). Although her first approach was aimed to the construction of private houses, in which she examined the potential of existenzminimum, as a refuge from the complexities of contemporary urban life. The weekend houses designed with Badovici since the 1930s showed the implementation of minimum spaces in response to the new social needs that existed in France.

In June 1936 the radical and the socialist government was set up, led by President of Popular Front Léon Blum, in line with the new political actions for the working class with the institution of the first paid holidays. Following these changes temporary housings solutions were starting to become manifestos of architecture for leisure and proving grounds for the testing of new technological solutions ${ }^{2}$.

Eileen extended her reasoning about minimum temporary spaces primarily to the human needs of the individual, exploring programs and forms able to act on both freedom and individuality, in line with her tendency to define spaces where it was always possible to get smaller sites for privacy. L'Architecture d'Aujourd'hui encouraged the building of individual facilities for leisure through a series of competitions, such as those for "a week-end house" (193435) and a "week-end city on the Mediterranean coast" (1935-36) ${ }^{3}$, with particular interest on marine sites and the chance to organize large areas with functional elements.

Embracing this new trend Eileen almost in contradiction with her exotic, complex and heterogeneous approach to the architecture of previous years,

1. Caroline Constant, Eileen Gray (London: Phaidon, 2000).

2. Peter Adam, Eileen Gray her life and work (New York: Thames \& Hudson, 2009), 120.

3. Constant, Eileen Gray, 171. 
interfaced herself with a spatial rigor of volumes and materials that enabled her to experiment with several minimum weekend houses. Her manifesto for a minimal and low-cost architecture certainly was the series of temporary houses designed for the Centre de Vacances et de Loisirs of 1936-37 and the Centre Culturel et Social of 1946-47, through which Eileen experimented the urban and landscape scale ${ }^{4}$.

Her references were the private houses designed by her in the previous decade. In L'Architecture d'Aujourd'hui, Eileen and Badovici had already defined the $E .1027$ "the minimum house, a minimum of space, comfort, mobile and fixed units"; according to Caroline Constant, probably this suggestion derived from the second Congrès Internationaux d'Architecture Moderne held in Frankfurt titled "The subsistence Minimum Dwelling".

It is interesting to note that, in the same years, Eileen conceived the maison type, identified with her E.1027, in relation to her weekend house schemes. Indeed, she claimed: «[...] To me, a maison type is only a house whose construction was carried out in accordance to the lowest cost and whose architecture reaches the highest perfection for each situation: it is a model, not to be reproduced ad infinitum, but that inspires the construction of other houses in the same spirit» ${ }^{6}$.

Once again, the gaze of Eileen highlights an important difference between the concept of "type", as the mere standardization of the prefabricated module and the meaning of a place's "spirit" declinable to the model not as a copy but as a free volumetric interpretation of similar spaces and architecture.

She proposed solutions that would encourage the occupants to participate in the formal composition of space. This feeling realizes the ideological consistency between both the buildings and the unbuilt projects of Gray; indeed, to understand social life, her main interest was to interpret desires and passions of the individual ${ }^{7}$.

Gray focused more on solving problems related to minimum single-family houses that were conceived as independent from the site. Their modular configuration would allow easy disassembling and transport; in line with Friedrich Engels' theory, according to whom the primary need of the workers was freedom in movement, an emblem of independence from the impediment of private property ${ }^{8}$.

She read many writings about the thoughts of Vladimir Ilyich Lenin and Leon Trotsky, but in her projects for leisure, she shows her divergence from the Bolshevik extremist positions always preserving a sort of individuality in through the flexibility achieved from modular construction ${ }^{9}$.

\footnotetext{
168.

4. Francesco Maggio, Eileen Gray. Interpretazioni grafiche (Milan: Franco Angeli, 2011),

5. Constant, Eileen Gray, 166.

6. Eileen Gray and Jean Badovici, "De l'éclecticisme au doute," in L'Architecture Vivante (1929), 21.

7. Adam, Eileen Gray her life and work.

8. Frederick Engels, The Housing Question (New York: International Publisher, 1935), 50.

9. Adam, Eileen Gray her life and work.
} 
Graphic Interpretations

Proceeding with the study of some of Eileen's projects on minimum houses for leisure, it wants to recognize, through the practice of graphical analysis a survey methodology, which provides an interpretation of the basic elements of Eileen's design.

Figure 1. Sketches of "Cabines Démontables pour Centre de Vacances" Source: by Eileen Gray.

The archive drawings (Figure 1), on which this graphic analysis is based, for the Cabines démontables pour Centre de vacances, consist of:

- 3 sketches of plans of temporary single-family houses

- 1 elevation.

Regarding the Maison en ellipse with one and two units:

- 1 plan

- 2 elevations.

The redrawing deal with the three Cabines démontables of 1936, regards:

- 1 plan

- 4 elevations

- 2 sections

- 1 exploded isometric drawing

- An analysis of harmonic ratios that define the geometric proportions.

In the drawing of the first cabine démontable by Eileen Gray, the rooms in the plan are the kitchen, dining room, two bedrooms and a bathroom with a 
shower ${ }^{10}$. Regarding the redrawing of the fixtures, without a graphical indication present, it is assumed that the single line, traced by Eileen in correspondence to the dining room compared to the rest of the envelope drawn with double-lines, could notify the presence of a glass surface ${ }^{11}$. In addition, the entrance has been identified in the redrawn plan, although there is no trace of this in the sketch, for the presence of the ramp to connect to the $40 \mathrm{~cm}$ in height that it reaches in the dining room, as she designs in the other two modules reported here (Figure 2).
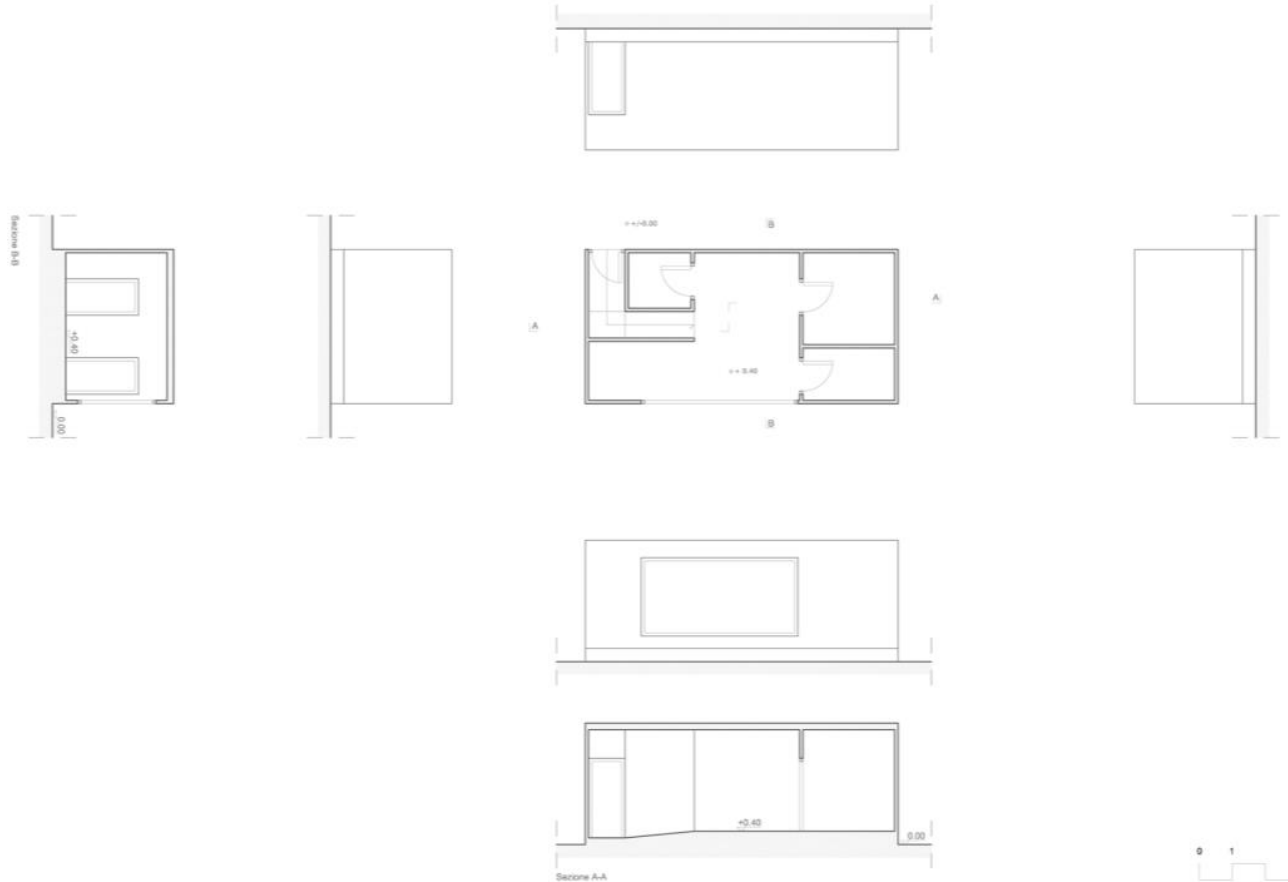

Figure 2. Graphic Interpretations of the First "Cabine Démontable pour Centre de Vacances". Plan, Sections and Elevations Source: by Starlight Vattano.

Regarding the graphical analysis, in plan can be traced harmonic ratios as diagonea (ratio $1: \sqrt{2}$ ) and a major third (ratio 4:5) while the facade contains a diapason (ratio 1:2) $)^{12}$.

Important information given by this kind of analysis shows how the ability of Eileen in combining spatial volumes and elements created minimum and at

10. In the drawing, Eileen writes "Cuisine", reporting also the sketch of a table with chairs and the abbreviation "Ch" referring to the French word "Chambre" in correspondence with the two bedrooms; finally, with the annotation "Salle d'eau" she identifies the bathroom with a shower.

11. In the graphic interpretation phase, in line with this reasoning, and dealing with a communicative process between the inquiring-self and the inquired-self, a window in correspondence with the dining room, has been traced.

12. The identified space inscribed into the major third maybe correspond to a previous version of the living unit, as it is deleted in plan, but it is still in the façade obtained below of the sheet. Contrariwise the plan of the drawing we can find a diagonea and a golden rectangle

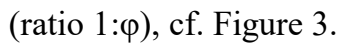


the same time functional spaces where the furnishing of different rooms are conceived specifically for only one space of the house.

They are conceived to be inserted within the architecture in a rational way: heights, base dimensions and modularity rise from the pragmatic feminine modus operandi of Eileen Gray.

The sketch of the second cabine démontable's plan backs annotation of a kitchen (which indicates the size of the stove top) and a bathroom with a shower ${ }^{13}$, while the other two rooms, the dining room and bedroom, can be identified by the furnishings which Eileen transformed into real delimitation "devices" of the interior spaces.

In this sketch the glass surface that develops almost for one entire side ending at the corner is easily detectable (Figure 1) and it enables the entrance of natural lighting in the living space.

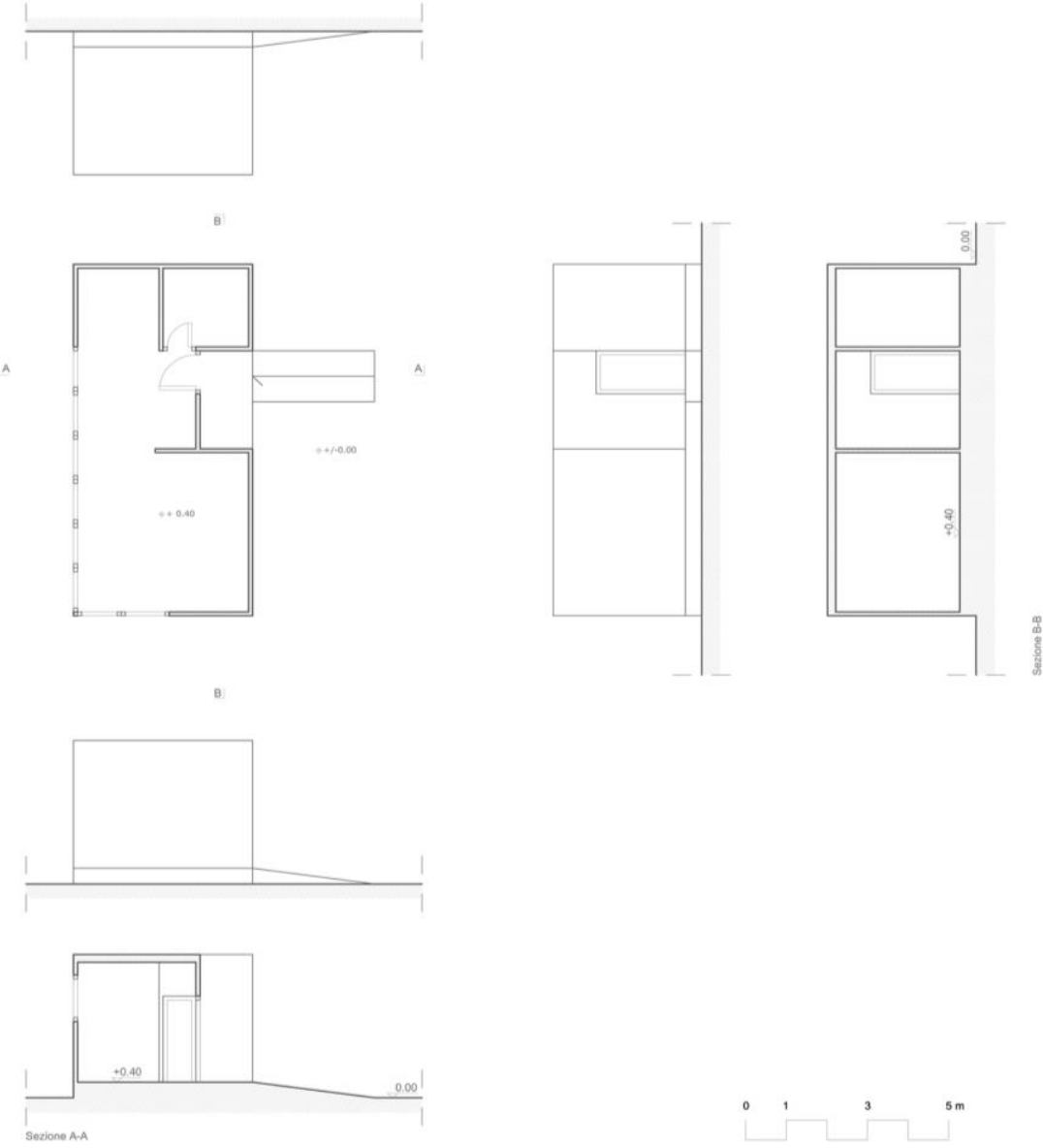

Figure 3. Graphic Interpretations of the Second "Cabine Démontable pour Centre de Vacances". Plan, Sections and Elevations Source: by Starlight Vattano.

Although in this case there is no trace of projection lines illustrating the overhang of a shelter protecting from direct internal solar irradiation, it would

13. In this sketch, the only notations reported into the two spaces at the right of the entrance are "Cuisine" and "Salle d'eau". 
be possible to imagine the presence of this architectural element (Figure 3). Indeed, the detailed condition of analysed sketches allows the interpenetration between what is not graphically manifested and the project hypothesis deducted for its similarity to other minimum housing models. The redrawing of this housing module traces in plan the ratios of a diagonea $(1: \sqrt{2})$ and of a golden section $(1: \varphi)$.
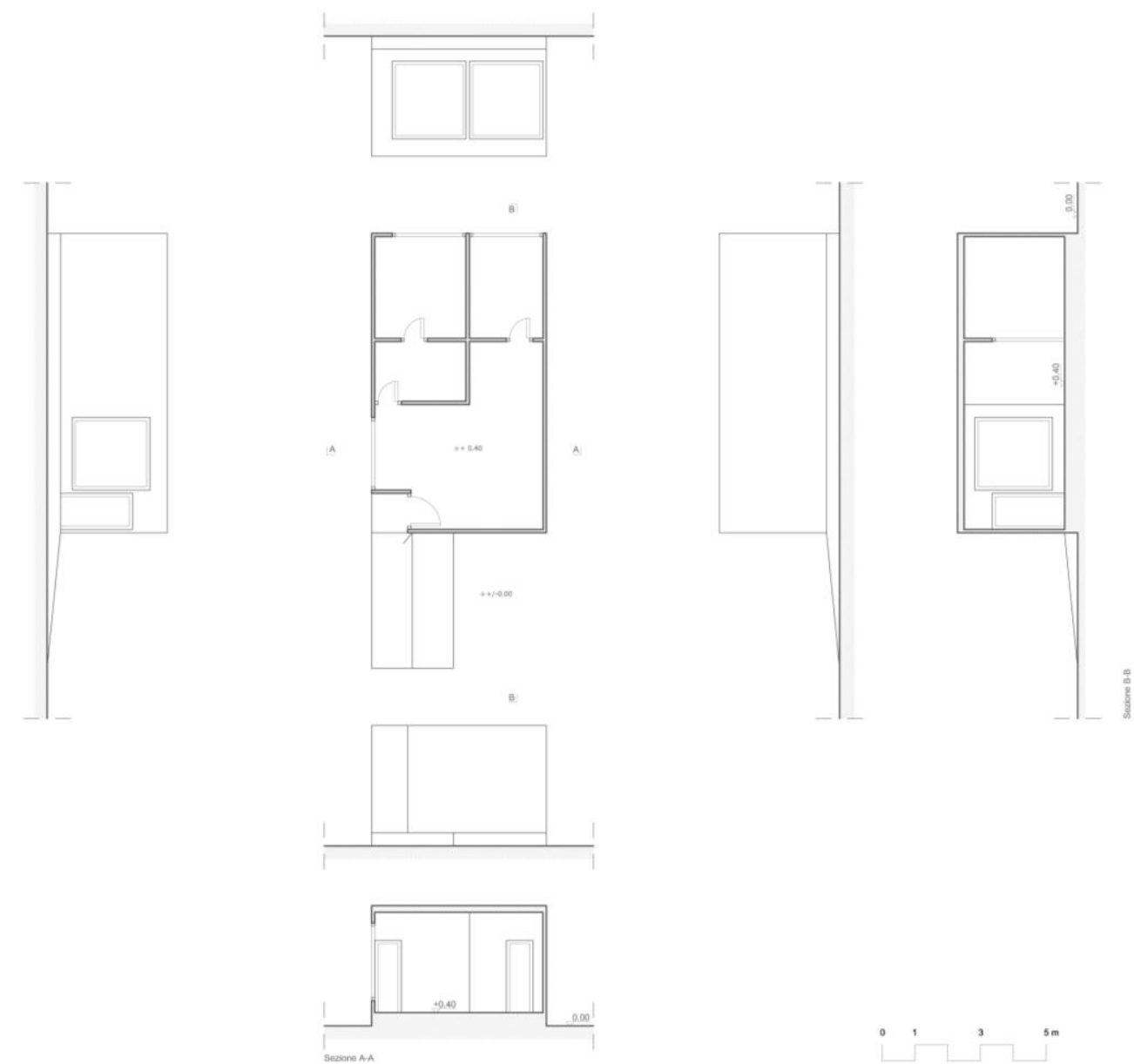

Figure 4. Graphic Interpretations of the Third "Cabine Démontable pour Centre de Vacances". Plan, Sections and Elevations

Source: by Starlight Vattano.

In the sketch of the third cabine démontable there are no annotations, but we can find the indication of furniture in the two bedrooms, bathroom, kitchen and dining room (Figure 1).

Also in this case there aren't graphic notations about the windows, so their placement in the plan has been hypothesized referring to the different signs of the envelope (with single or double line), as suggested previously (Figure 4). In this module, the harmonic ratios are a diatessaron (ratio 3:4), a diapason diatessaron (ratio 3:8) and a golden section (1: $\varphi$ ) (Figure 5). 

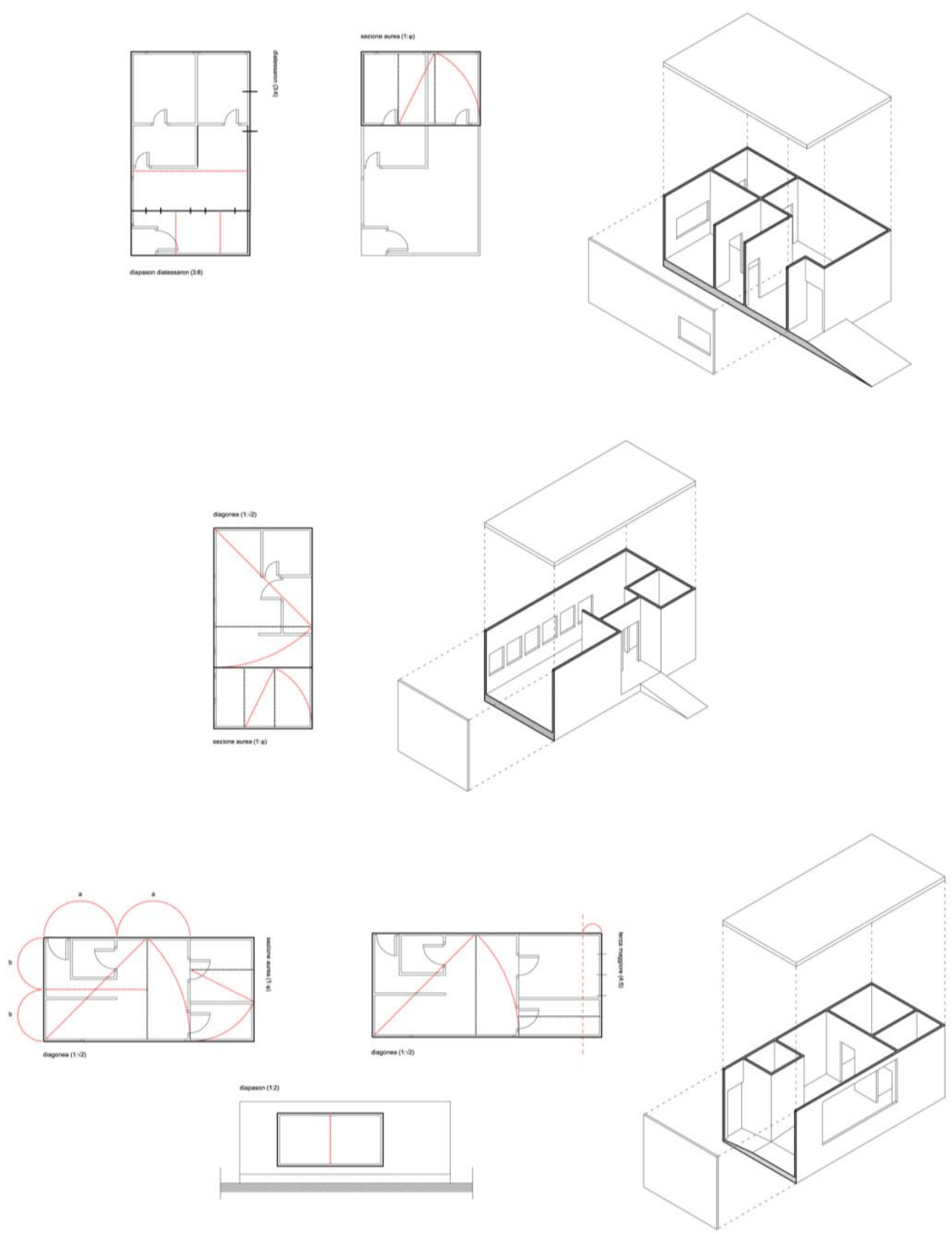

Figure 5. Harmonic Ratios and Axonometric Schemes of "Cabines Démontables pour Centre de Vacances"

Source: by Starlight Vattano.

The redrawing of the Maison en ellipse of 1936 with one and two units develops from the plan drawn by Eileen with two assembled modules $(7.50 \mathrm{~m}$ per module) and the bedrooms' furniture (Figure 6). Concerning the identification of harmonic ratios, in the plan with a single module a double diapente $(4: 9)$ has been traced, while in that with two modules a major sixth (3:5) and a division into three parts in correspondence of the three bedrooms. 

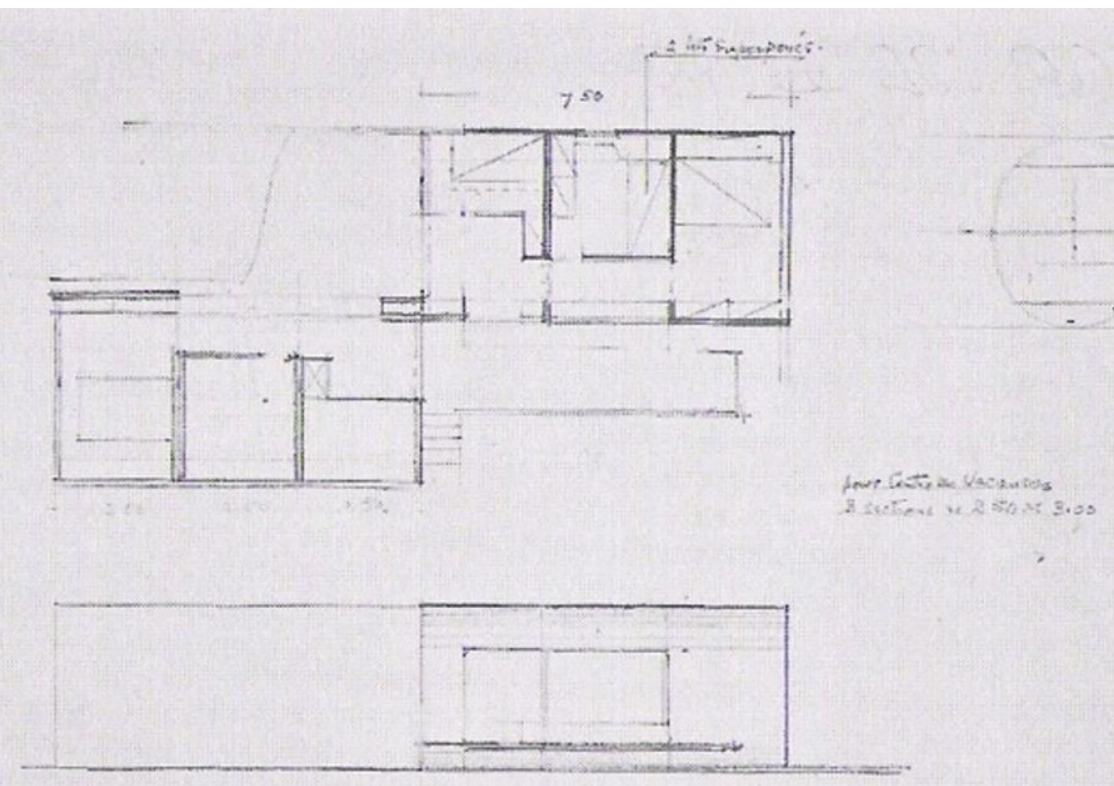

Figure 6. Drawings of "Maison en Ellipse"

Source: by Eileen Gray.

For this project, Eileen states: «Prefab concrete houses, made to be by easily transportable by truck. Advantages. A single frame. To connect the elements just need to assemble them. Mass-produced, these houses would be economic for the Centre de Vacances and might also temporarily serve to the homeless. Insulation: plasterboard and glass fibre» ${ }^{14}$. We trace, in these annotations, the desire to simplify the installation and transport of the minimum houses designed for movement and spatial flexibility, low cost and with attention to detail (Figure 7). In this project, we can find the compositional elements of the Camping Tent of 1930 about the provisional aspect of architecture, combining them with the natural attitude of Eileen to the experimentation of form and material. Inspired by the aluminium caravan published in the periodicals French Touring Club in 1935 and by the mass production techniques adopted to manufacture them, she conceived a small unit of prefabricated concrete panels, quickly, to assemble on pointed-foundations. These principles of lightness, easy installation and waterproof had already been proposed in the project published in L'Architecture d'Aujourd'hui by Henri Sauvages in his standardized fibre-cement house. Even in her project on the Maison en ellipse Eileen thinks about a covered porch and conceives the modular interior with mobile furniture to provide a high degree of internal flexibility. From the observation of the sketches, we notice an architectural envelope consisting of prefabricated elements that assume the final configuration of a typical temporary house. The principle of disassembling and reassembling of simple volumes characterizes the cabines démontables pour

14. Stefan Hecker and Christian F. Müller, Eileen Gray (Barcelona: Gustavo Gili, 1993), 205. 
centre de vacances, with the possibility to obtain different modular configurations, depending on the number of a unit's inhabitants.
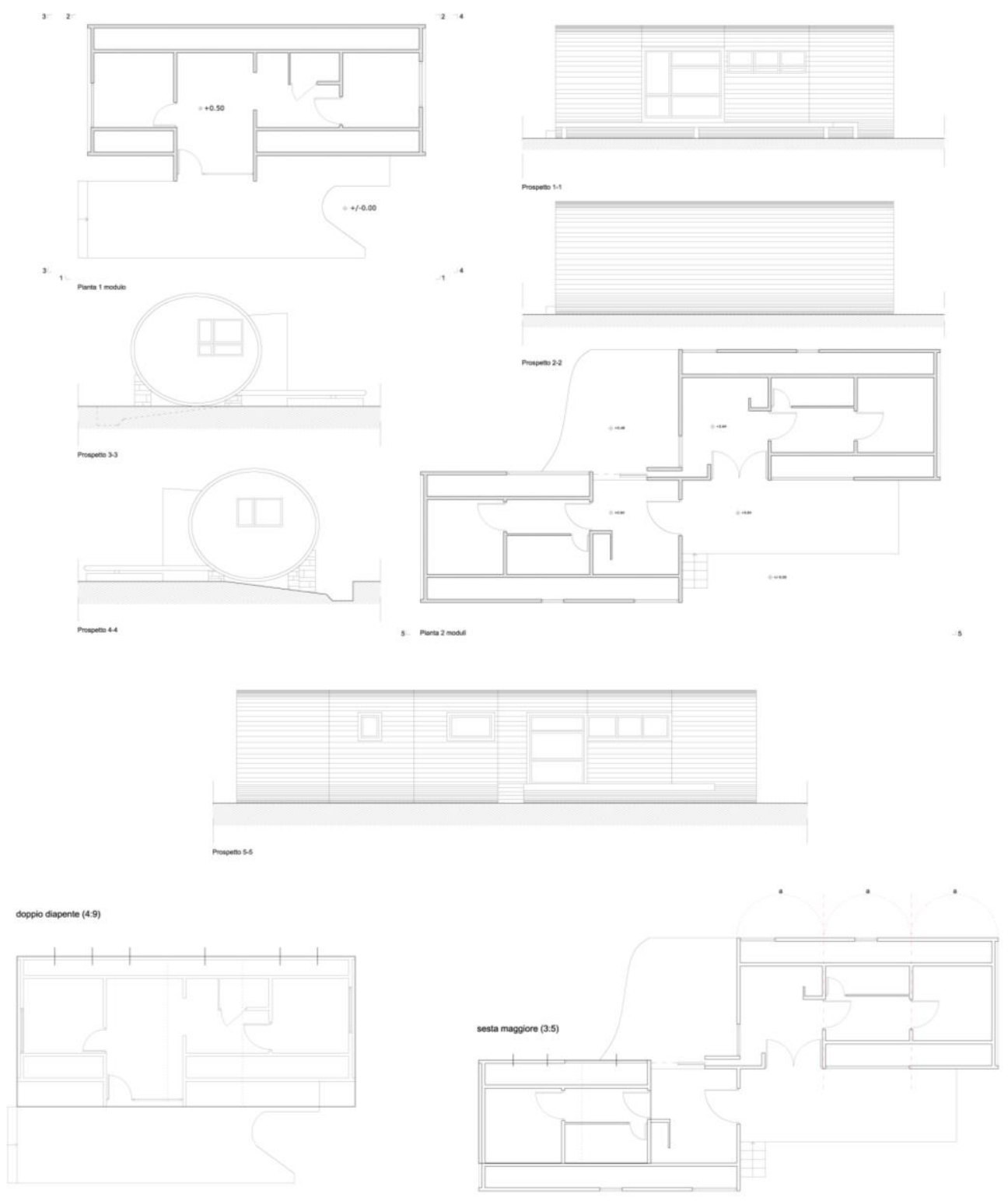

Figure 7. Graphic Interpretations of "Maison en Ellipse" Source: by Starlight Vattano.

Each module has a private entrance, which emphasizes the intimate inflection of Eileen Gray to conceive spaces through her architectural empathy, while providing spatial flexibility and isolation.

The last point characterizing Eileen's temporary architecture is the organization of spaces through the placement, in strategic points, of furniture, which constitutes real screen elements of the internal environment and 
becomes a constant feature in the spatial definition of her minimum weekend houses. Indeed Hecker and Müller write that Eileen «puts the "lived" space to the neutral functional skin. In other words: the space obtained does not configure only purely architectural requirements, but it is the result of interaction of essential items for the performance of daily life» ${ }^{15}$.

Finally, in the projects of cabines démontables analysed, Eileen experiences different configurations of minimum spaces, developing on one level lightweight structures composed of prefabricated panels with steel, raised from the ground through a basement (Figure 8).

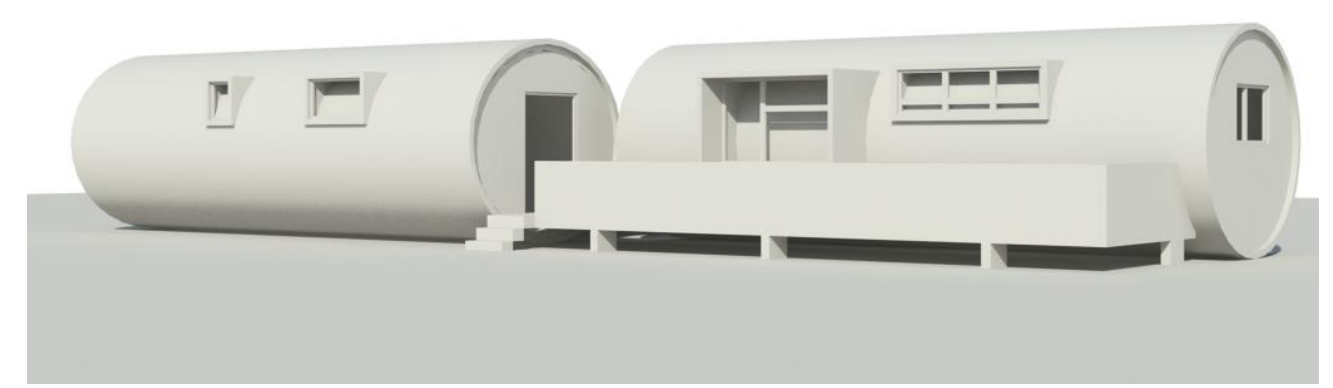

Figure 8. Render of "Maison en Ellipse" with Two Modules

Source: by Starlight Vattano.

Generally, the shell is adjusted according to the prefabricated elements. Indeed, in cabines démontables she uses panels, measuring $2.00 \times 2.10 \mathrm{~m}$ and $1.00 \times 2.10 \mathrm{~m}$ and that define the modularity adopted in the project ${ }^{16}$.

The lightness of the materials, prefabrication, modularity and flexibility in the furnishing space characterize her minimum weekend architecture, conceived as camping tents and at the same time housings in which satisfy the highest levels of interior comfort. Sketch and annotation become a whole in the graphic expression of Eileen Gray. They become a message that assumes the material relevance and form through the identification of the inquiring subject into the drawn project. In this way, drawings remain hanging in a paper support that becomes the midpoint of the dual segment, constituted by Eileen of the past and Eileen of the present.

\section{Charlotte Perriand}

The independent and anticonformist figure, Charlotte Perriand, completely found an important role in the architecture scenery of the XX century becoming one of the Modern Movement pioneers and contributing to the definition of a new femininity thanks her determination and her view of the modern woman. Even if in the Art Déco period spread in France, Perriand

15. Hecker and Müller, Eileen Gray, 163.

16. Ibid., 204. 
understood that the emblems of that art belonged to the past and that the spaces, pure geometry, light, new materials, machines and factories would take the place of the decorative art.

Charlotte Perriand loved the present but looked to the future, she was fascinated by cars, by their curved shapes and their bodywork. She realized that the age of machines represented a humanist ideal, which made human life easier and more comfortable. The reading of the Vers une Architecture e L'art décoratif d'aujourd'hui written by Le Corbusier allowed her to know the view of a man close to her modern vision of life, that was evolving from a domestic ideal, anchored to the decorative art, to a functional and rational one. Today her figure is still known mostly for her interior design activities, rather than the architectural ones, even though many documents testify her experience as a building designer.

Charlotte Perriands' trajectory was neither linear nor premeditated. She proceeded by leaps that led her from one setting to the next, with return loops to themes that had mostly inspired her.

She started her work with the rue de Sèvres study, to the left of Le Corbusier and Pierre Jeanneret as a partner in charge of the furniture. Le Corbusier had understood Charlotte was right to complete his program about the humanization of interior design and to develop his concept of "furniture to live". After the first years of collaboration, Perriand specialised independently in prefabricated architecture for recreational purposes and built a series of vacation houses that could be used by a great number of people.

In the early 30's, before the Popular Front rose to power in France in 1936, Perriand found the organisation of leisure as one of the most "urgent problems" to resolve. Le Corbusier wrote about it: "The recreations of the age of the machine, from the first day of the reorganisation of production, emerge as a social danger: imminent threat. Soon, inevitably, the organisation of production will open up vacant hours each day for everyone... This is one of the most troubling problems of contemporary sociology. We therefore feel the need to quickly transform the unformed acceptance of leisure into a disciplined function. We cannot waste seven to eight hours a day to millions of men and women and young people in the streets"17. Similar to other architects, Perriand participated in various competitions, including the one organised by the journal L'Architecture d'Aujourd'hui to design a week-end house. The competition requested to plan an inexpensive weekend house, designed to be built on the riverbanks and to lodge a five people family and two guests. Perriand worked out two solutions: the first one, the Maison du week-end, through which she received the second prize, and the second one, known as Maison au bord de l'eau (Figure 9), which remained on paper but whose prototype was faithfully built by Cassina according to the vintage plans under the direction of Perriand's daughter, Pernette, and Louis Vuitton's support.

17. Le Corbusier, La Ville Radieuse (1933), 64. 


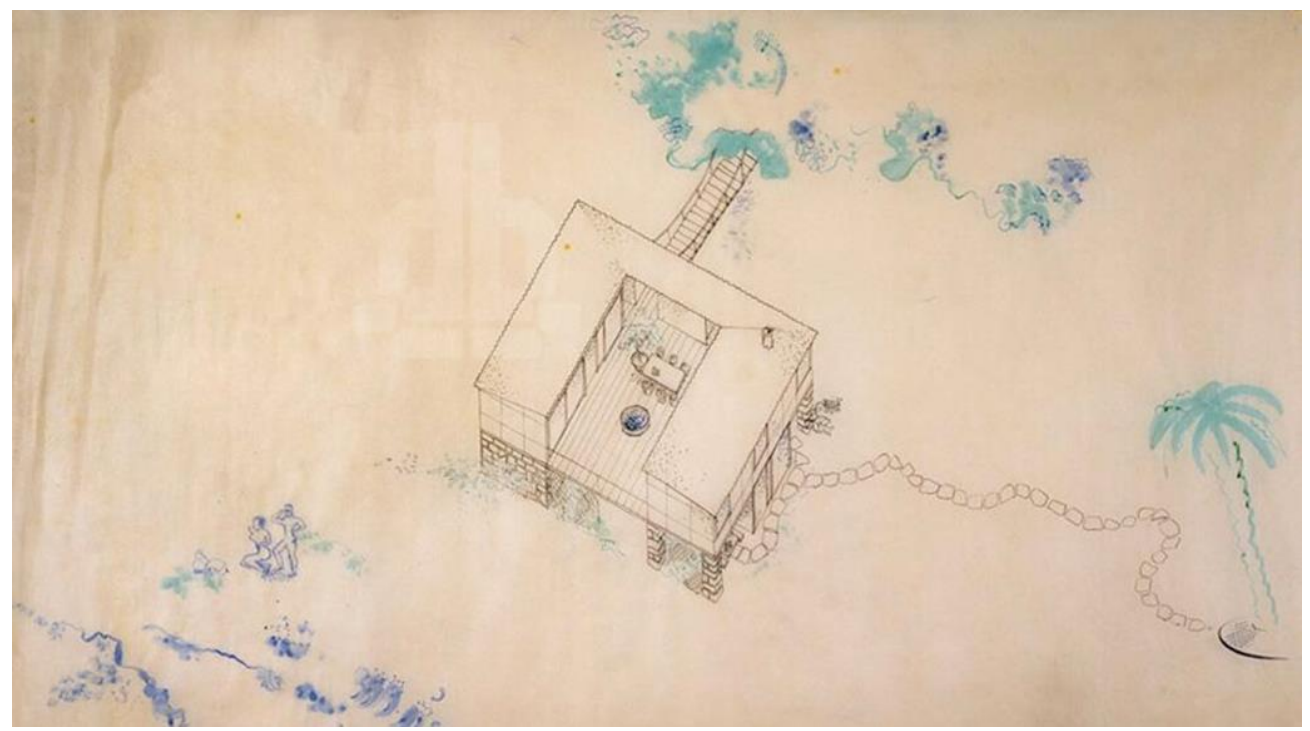

Figure 9. Sketches of the "Maison au Bord de l'Eau"

Source: by Charlotte Perriand.

The project itself was most likely inspired by the modest fishermen's houses built on pilots around Arcachon Bay, which she had seen while she was on vacation with Le Corbusier and Jeanneret in $1934^{18}$.

The main elements could be built industrially: metal frame, floor panels, interior and exterior walls, ceilings. These elements could be mounted in various arrangements depending on the site. Inspired by the campers' inventiveness, Charlotte Perriand planned a flexible house, produced in a series, designed for modules and delivered in a mounting box, whose foundations would be realized with local stones.

\section{Graphic Interpretations}

By the graphical analysis, as a critical-communicative tool, it is possible to investigate the Maison $d u$ weekend, one of the most important projects designed by Charlotte Perriand about habitation minimun for recreation at an economic price. This graphic practice is very useful to interpret the design process, particularly because it is an unrealized project, about which it is impossible to have some direct information to get formal and spatial values. These vintage drawings include: a plan, three sections, three facades and an axonometric scheme.

The graphic reworks realized, starting by the drawings listed above, concern a plan, four sections, four facades, an axonometric scheme, functional schemes and a digital model. The last one represents the synthesis of all the other representations and the various hermeneutics declinations resulted from these ${ }^{19}$.

18. Jacques Barsac, Charlotte Perriand. Complete works (Zurigo: Scheidegger \& Spiess, 2014) 302 .

19. Riccardo Migliari (ed.), Disegno come modello (Roma: Kappa, 2004), 6. 
The project idea presented two symmetrical volumes facing one another and opening into a wood terrace raised on pilots above the level of the river. The whole structure designed, was supported by stone pillars. In this way, you could get a distance from the waters of the river and have a healthy and liveable construction without interferences. As she said in the competition text, she intended to design a wooden tent, a free space for the ingenuity of its tenants, without further internal developments. Charlotte Perriand gave up defining interior spaces to allowing the tenants who lived there to participate to the formal interior composition.

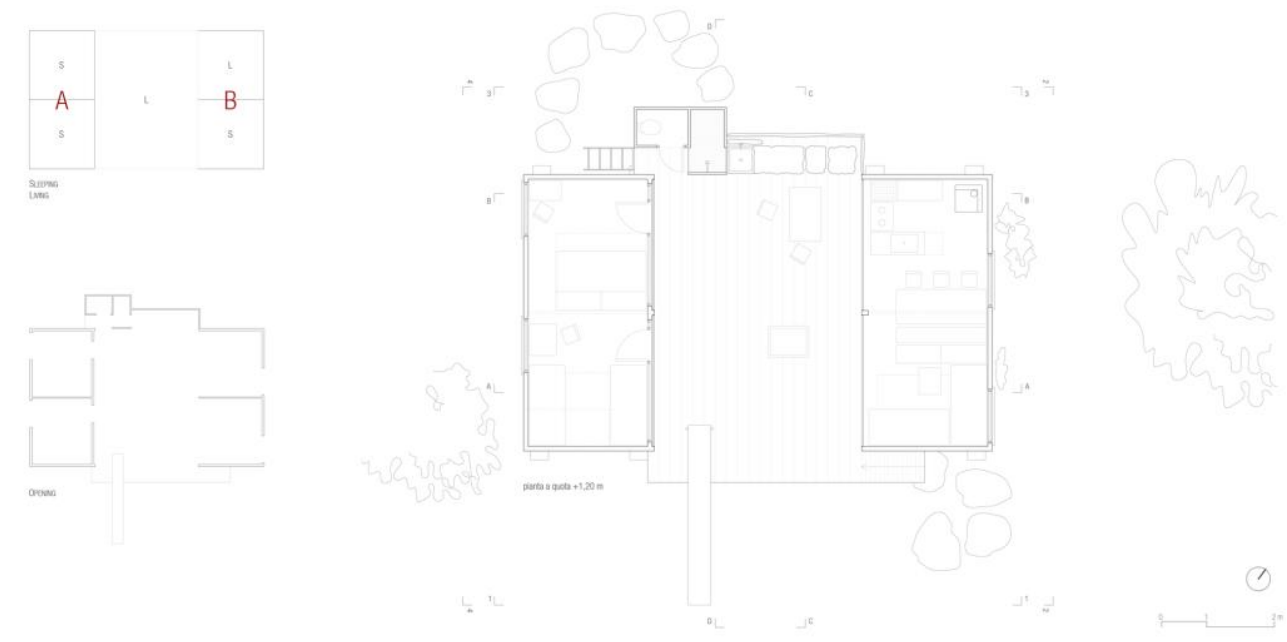

Figure 10. Graphic Interpretations of the "Maison du Week-end". Plan and Schemes

Source: by Giorgia Gaeta.

Through the studying of the plan, it has been possible to get a lot of information about the interior organisation (Figure 10). According to records drawn by Perriand, the A volume was intended for the family and the B volume for the guests and the kitchen.

The terrace was the living place, the real meeting place of the house. Wooden movable panels could isolate parts of the platform without removing the light or opening itself to protect it from the sun and the rain. This smart cover system allowed doubling the floor space of the house. The movable provided panels were four. Each of them was independent from the other one and allowed to isolate partially or totally, the different rooms according to the needs of the tenants, as it is evident from the sections. Through the plan you can also see that only two movable panels of the A volume show two little doors which allow the possibility to isolate oneself, while the B volume does not have it. This solution induces the tenants to come out of their indoor shelter and to enjoy the open space of the platform. Perriand moreover specifies the recommended orientation according to which the $\mathrm{WC}$ and the kitchen are on the north to repair the other spaces from cold winds, the parents' bedroom on the north-west, the children's bedroom on the south-west and the guests' bedroom on the south-east. The rooms placed in this way are visually 
connected by some diagonals, which intersect and translate in movement axes. The first diagonal is identified between the two stairs, the garage one and the other one that goes towards the river. A second diagonal axis is identified between the living area of the platform and the diving board The parallel axes that connect the parents' bedroom to the kitchen and the children's bedroom to the guests' one, emphasize the role of the bridge-platform.

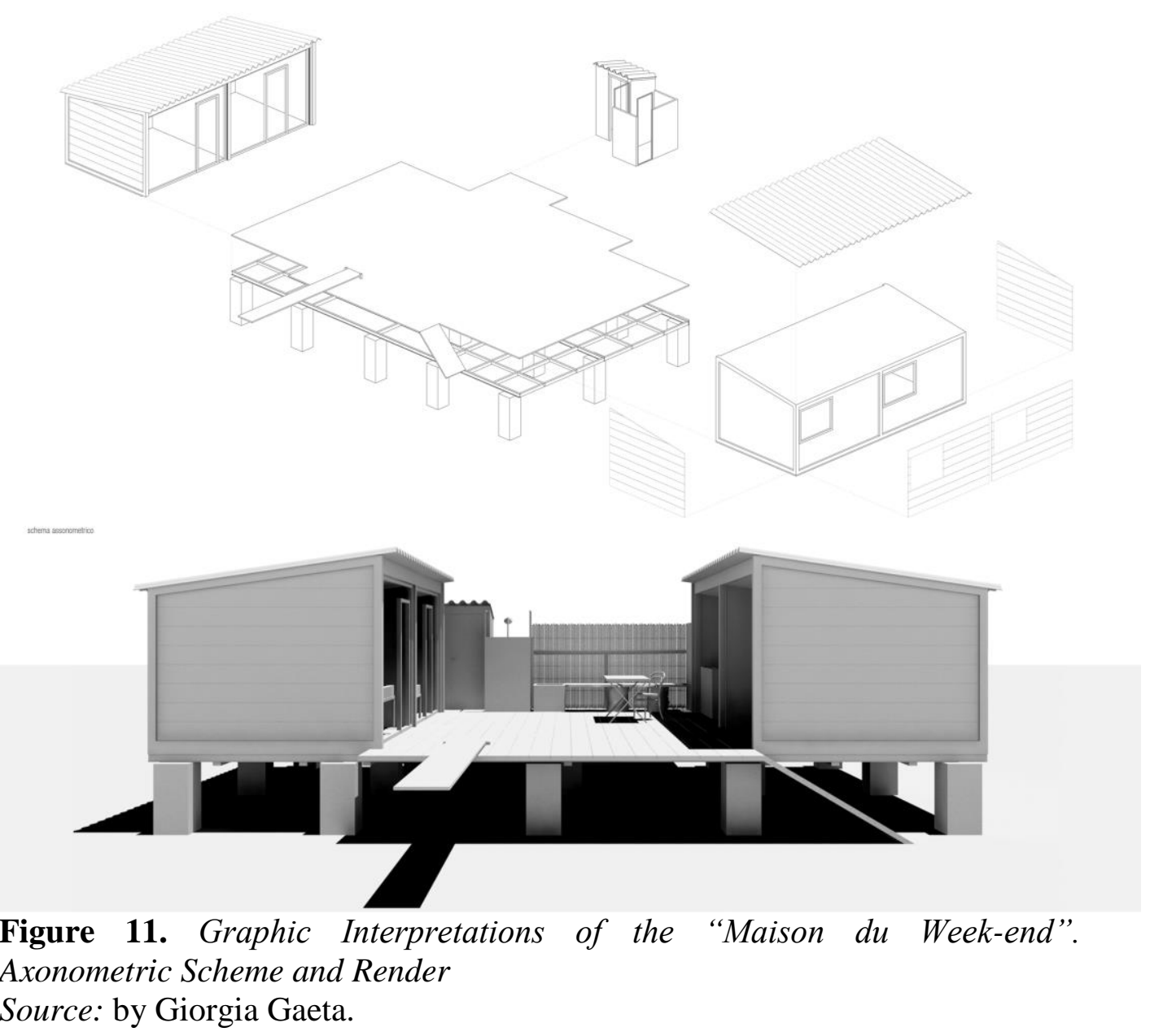

The axonometric scheme permits a better understanding of the spirit of Charlotte Perriand's idea (Figure 11). The fireplace, the garage, the diving board, the barbecue, the WC, are all elements that show how Perriand was trying to offer every possible comfort through simple and cheap solutions, following not only an economy of volumes but also of materials. 

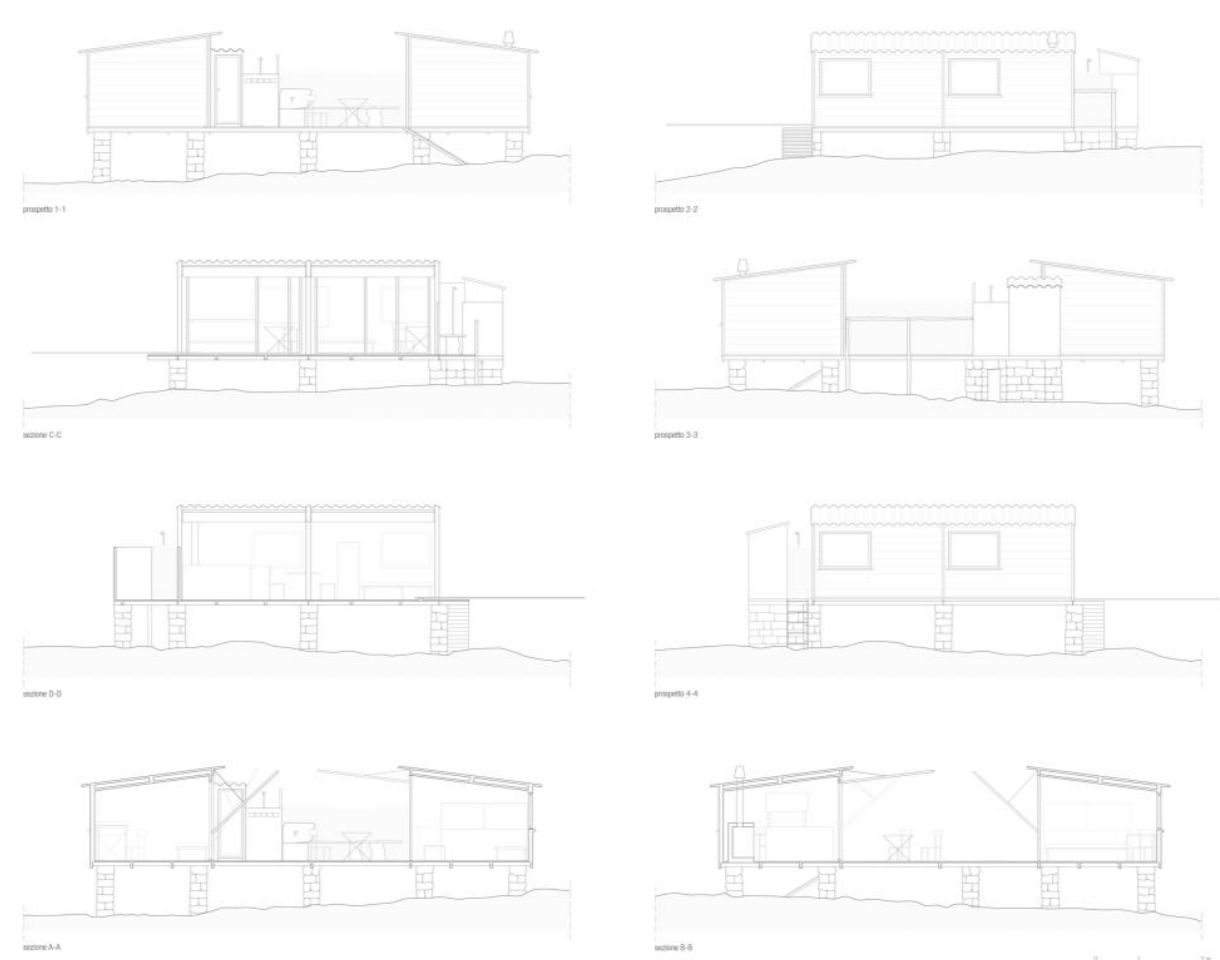

Figure 12. Graphic Interpretations of the "Maison du Week-end". Sections and Facades

Source: by Giorgia Gaeta

By the A-A and B-B sections you can get a lot of information about rotating panels, their operation, the covers and Charlotte Perriand's way of life, which she was trying to introduce with this plan. In the C-C section instead the placing of the $\mathrm{WC}$ on the platform, that gives an added value to the whole project, is evident. This section is also useful to make clear the height of the wooden panel which separates the two bedrooms of the A module that, differently from the one present in the B module, partially separates the two rooms without guaranteeing soundproofing (Figure 12).

Her solution to resolve the problem of the natural slope of land is interesting. Presenting her proposal about a slope, she demonstrates how this plan could be available to every place, because the main structure is completely free from the ground below.

At the same time, Perriand employs this aspect to place the garage below the platform. This solution clearly reveals the influence of Le Corbusier in her work. Such as in Villa Savoye, the car has its own role in the house. The modern family uses the car as a principal mean of transport. Charlotte Perriand explains that here, as in every residence, there will be a specific place to shelter it.

Charlotte Perriand's experience in planning houses like these, examples of minimal and economic price architecture, was important because it introduced her to the fundamental rules of human life in a minimum space and also because it made her fight for flexible, new and practical solutions useful for her 
future works. Through this plan, Perriand emphasized the collective and rational way of life. Her work in fact reflected her age tendencies towards economy and the prosperity of middle classes. Studying minimum habitation, she found new directives for the integration and safeguard of public health. Besides the influence of Le Corbusier's residences in Weissenhof especially for the organization of inner spaces inspired to the sleeping car ones, Charlotte Perriand was affected by other architects of that time that laid the foundations of new ideas.

About twenty years before, in 1913, Adolf Loos wrote the rules for the mountain buildings: «Do not build in a picturesque manner. Leave such effect to the walls, the mountains and the sun ... Pay attention to the forms in which the locals build. For they are the fruits of wisdom gleaned from the past. But look for the origin of the forms. If technological advances made it possible to improve the form, then always use this improvement ... Be true! Nature only tolerates truth ${ }^{20}$. Therefore, Perriand refused the total integration with the environment based on natural shapes; on the contrary, she presented a rational shake that declared their artificiality and she approached the natural way of life using organic materials.

In her autobiography, she wrote: «Architecture proceeds from interior towards exterior; it is a coming and going movement. It must satisfy our needs, offer us the extension of our daily gestures, both in a house, in a hospital, in an embassy... It is necessary to keep in mind the man in his individual or collective dimension and his habits, his idiosyncrasies, the society in which he lives, the climate, the environment» ${ }^{21}$.

In her plans, Perriand introduced some basic but innovative concepts, such as the use of high technology materials in different combinations, the study of better inner comfort, the sizing and rationalization of spaces, the cooperation between factory and handicraft and the packing speed. All these elements confirm the diachronic universality of her resolutions.

Starting from the minimum, she reached the whole, keeping in mind that the new social conditions required houses for a modern, practical and independent man. Even if many of her works were not realized, she revealed her bright methodology of a free and a creative mind.

\section{Conclusions}

The recurring elements of minimum houses by Eileen Gray and Charlotte Perriand have been traced through the practice of redrawing.

Folding and removable structures that assume different configurations depending on the needs of people, are the characteristics that define and capture two female images of modern architecture, through which it is possible

20. Adolf Opel, Adolf Loos. Die potemkin'sche Stadt: verschollene Schriften 1987-1933 (Vienna: G. Prachnercop, 1983), 16.

21. Charlotte Perriand, Io Charlotte, tra Le Corbusier, Léger e Jeanneret (Roma-Bari: Laterza, 2006), 28. 
to trace the key element not only on a small-scale, that of the detail and furnishing, but also on a large scale. Showing once again that, while remaining clouded by the figures that were not subject to the gender condition, the architecture is an emotional attitude, through which building new ways of knowing and investigating the size of the spaces, the functional organization and the arrangement of furniture, reaching the best internal comfort both spatial and physical one.

The practice of the "graphic interpretation" of very poor data about projects here selected represents a different way to study and understand architecture. Indeed, at first it walks with the designer itself and shows specific archive data of the project, often very few, and then, once enriched through new drawings, functional schemes and renderings it gives more information about the project of architecture and the possible mental processes that the designer had followed.

The field of investigation of these reflections remains the drawing of the architecture conceived as a project, such as the reading and word of the "thing investigated" that constantly turns and assumes, at the end, one of the infinite possible configurations.

\section{Bibliography}

Adam, Peter. Eileen Gray her life and work. New York: Thames \& Hudson, 2009.

Barsac, Jacques. Charlotte Perriand. Complete works. Zurigo: Scheidegger \& Spiess, 2014.

Constant, Caroline. Eileen Gray. London: Phaidon, 2000.

Engels, Frederick. The Housing Question. New York: International Publisher, 1935.

Gray, Eileen and Jean Badovici. "De 1'éclecticisme au doute." [From Eclecticism to doubt.] In L'Architecture Vivante, 17- 35. Winter, 1929.

Hecker, Stefan and Christian F. Müller. Eileen Gray. Barcellona: Gustavo Gili, 1993.

Le Corbusier. La Ville Radieuse [The Radiant City], 1933.

Maggio, Francesco. Eileen Gray. Interpretazioni grafiche. [Eileen Gray. Graphical Interpretations.] Milano: Franco Angeli, 2011.

Migliari, Riccardo (ed.). Disegno come modello. [Drawing as model.] Rome: Kappa, 2004.

Opel, Adolf. Adolf Loos. Die potemkin'sche Stadt: verschollene Schriften 1987- 1933. [Adolf Loos. The Potemkin City: lost writings 1987-1933.] Vienna: G. Prachnercop, 1983.

Perriand, Charlotte. Io, Charlotte tra Le Corbusier, Léger e Jeanneret. [I, Charlotte between Le Corbusier, Léger and Jeanneret.] Roma-Bari: Edizioni Laterza, 2006.

In the sharing of positions expressed in the article, the result of common elaborations, the paragraph "Eileen Gray. "Cabines Démontables pour Centre de Vacances" was written by Starlight Vattano; the paragraph "Charlotte Perriand” was written by Giorgia Gaeta, while the introduction and the conclusions are by the two authors. 